\title{
Field Analyses of Tritium at Environmental Levels
}

by

K. J. Hofstetter

Westinghouse Savannah River Company

Savannah River Site

Aiken, South Carolina 29808

P. R. Cable

D. M. Beals

J. E. Noakes

Center for Applied Isotope Studies

GA USA

J. D. Spaulding

Center for Applied Isotope Studies GA USA

M. P. Neary

Center for Applied Isotope Studies

GA USA

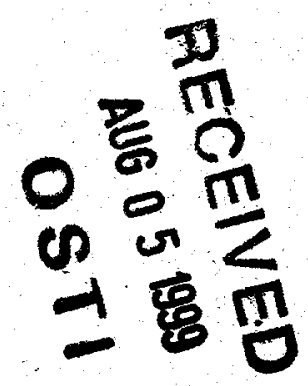

R. Péterson

Sampling Systems, Inc.

TX

USA

A document prepared for TO BE PUBLISHED IN PROCEEDINGS: SYMPOSIUM OF RADIATION MEASUREMENTS AND APPLICATIONS/NUCLEAR INSTRUMENTS AND METHODS IN ENERGY RESEARCH at Ann Arbor, MI, USA from 5/12/98 - 5/14/98.

\section{DOE Contract No. DE-AC09-89SR18035}

This paper was prepared in connection with work done under the above contract number with the U.S. Department of Energy. By acceptance of this paper, the publisher and/or recipient acknowledges the U.S. Government's right to retain a nonexclusive, royalty-free license in and to any copyright covering this paper, along with the right to reproduce and to authorize others to reproduce all or part of the copyrighted paper. 


\section{DISCLAIMER}

This report was prepared as an account of work sponsored by an agency of the United States Government. Neither the United States Government nor any agency thereof, nor any of their employees, makes any warranty, express or implied, or assumes any legal liability or responsibility for the accuracy, completeness, or usefulness of any information, apparatus, product, or process disclosed, or represents that its use would not infringe privately owned rights. Reference herein to any specific commercial product, process, or service by trade name, trademark, manufacturer, or otherwise does not necessarily constitute or imply its endorsement, recommendation, or favoring by the United States Government or any agency thereof. The views and opinions of authors expressed herein do not necessarily state or reflect those of the United States Government or any agency thereof.

This report has been reproduced directly from the best available copy.

Available to DOE and DOE contractors from the Office of Scientific and Technical Information, P.O. Box 62, Oak Ridge, TN 37831; prices available from (615) 576-8401.

Available to the public from the National Technical Information Service, U.S. Department of Commerce, 5285 Port Royal Road, Springfield, VA 22161. 


\section{DISCLAIMER}

Portions of this document may be illegible in electronic image products. Images are produced from the best available original document. 


\title{
Field analyses of tritium at environmental levels
}

\author{
K. J. Hofstetter, P. R. Cable, D. M. Beals, \\ Westinghouse Savannah River Company \\ Savannah River Technology Center \\ Aiken, SC 29808
}

\begin{abstract}
Testing of an automated, remote system to analyze tritium in aqueous solutions at environmental levels has been accomplished. The field deployable tritium analysis system (FDTAS) has demonstrated laboratory quality tritium analysis capability in near real-time. The FDTAS consists of a novel multi-port autosampler, an on-line water purification system, and a prototype stop-flow liquid scintillation counter (LSC) which can be remotely controlled for unmanned operation. Backgrounds of $\sim 1.5$ counts per minute in the tritium channel are routinely measured with a tritium detection efficiency of $\sim 25 \%$ for the custom $11 \mathrm{~mL}$ cell. A detection limit of $<0.3 \mathrm{pCi} / \mathrm{mL}(<10 \mathrm{~Bq} / \mathrm{L})$ has been achieved for 100-minute counts using a 50:50 mixture of sample and cocktail. To assess the long-term performance characteristics of the FDTAS, a composite sampler was installed on the Savannah River, downstream of the Savannah River Site, and collected repetitive 12-hour composite samples over a 14 day period. The samples were analyzed using the FDTAS and in the laboratory using a standard bench-top LSC. The results of the tritium analyses by the FDTAS and by the laboratory LSC were consistent for comparable counting times at the typical river tritium background levels $(\sim 1 \mathrm{pCi} / \mathrm{mL})$.
\end{abstract}

\section{Introduction}

A system has been developed through the cooperation of university, government, and private industry scientists and engineers to analyze tritium in aqueous solutions at environmental levels. This completely automated sampling and analysis system can be placed in a remote location for long-term monitoring of ground or surface water and can detect tritium at environmental background levels. The field deployable tritium analysis system (FDTAS) has achieved laboratory quality tritium analyses in near real-time. The FDTAS consists of a novel multi-port autosampler which collects $50 \mathrm{~mL}$ of sample, an on-line water purification system which employs single-use resin columns, and a prototype stop-flow liquid scintillation counter (LSC) for recording beta spectra. All of the components are remotely controlled for unmanned operation. A pneumatically operated, radioactive source $\left({ }^{241} \mathrm{Am}\right)$ functions as an external standard to verify cell filling and to perform quench corrections. A block diagram of the prototype FDTAS illustrating its multi-port ground water sampling capability is shown in Figure 1. A detailed description of the prototype FDTAS and the results of various field demonstrations at ground and surface water monitoring sites are given in earlier publications [1-3]. 
Laboratory tests of the various methods of purifying environmental samples which apply to unattended field deployment, led to the selection of single use, commercially available, mixed bed resin columns (footnote). The results of these optimization tests have been reported [4]. By employing active background suppression and pulse shape discrimination using bismuth germanate (BGO) guard scintillators, lead shielding and low background cell components, the FDTAS has achieved tritium detection sensitivities which rival laboratory LSC instruments. The combination of active BGO guard detectors and low background materials [5] results in routine backgrounds of $\sim 1.5$ counts per minute in the tritium channel. A special low background quartz counting cell with $11 \mathrm{~mL}$ of a 50:50 mixture of sample and Packard Ultima-Gold LLT liquid scintillation counting fluid yields a tritium detection efficiency of $\sim 25 \%$. The combination of low background, high detection efficiency, and $5.5 \mathrm{~mL}$ sample volume leads to a detection limit of $<0.3 \mathrm{pCi} / \mathrm{mL}$ for a 100 -minute count $(95 \%$ confidence limit). These figures of merit have been routinely achieved in the field tests of the FDTAS on ground water monitoring wells, surface streams, at ground water remediation facilities, at sewage treatment plants, and on the Savannah River. All the results have been confirmed by parallel sampling and laboratory analyses.

\section{Experimental}

While the many field deployments have confirmed the tritium detection sensitivity, remote operation, and purification capability under a variety of influent conditions, only a limited number of samples have been analyzed at each location using the field prototype. To assess the long-term performance characteristics (e.g., accuracy and precision) of the prototype FDTAS, one demonstration generated a large number of samples for analysis. A composite sampler was installed on the Savannah River, downstream of the Savannah River Site, which collected $10 \mathrm{~mL}$ of river water every 30 minutes for 12 hours. The sampler collected repetitive 12 -hour composite samples over a 14-day period. The samples were analyzed using the FDTAS and a laboratory-based LSC. The results of the tritium analyses by the FDTAS and the laboratory LSC are shown in Figure 2. For a 30-minute count on the laboratory LSC, the minimum detectable activity $(95 \% \mathrm{C}, \mathrm{L}$.) for the samples is $\sim 0.5 \mathrm{pCi} / \mathrm{mL}$. The laboratory analyses were performed in duplicate, where possible. Additionally, replicate analyses were performed with the FDTAS on several samples.

\subsection{Laboratory Analyses}

A 3-mL aliquot of each composite sample was mixed with $22 \mathrm{~mL}$ of Packard Optiflor liquid scintillation cocktail for analysis using a Model 2050 Packard TriCarb liquid scintillation counter. Duplicate samples were prepared from each composite. Each sample was counted for ten minutes and the sample changer advanced to the next sample position. The entire process was repeated three times to complete the counting cycle. This protocol ensures that the samples are adequately light and temperature adapted. A background blank and a tritium standard were counted with each set of samples. The Packard Tri-Carb is set to determine any quench corrections using quench calibration 
curves that have been verified by an internal tritium spike added to selected solutions.

A 50-mL aliquot of each composite sample was taken and purified through a separate EiChroM tritium column under gravity flow conditions. The first $20-\mathrm{mL}$ of sample was discarded, as experiments have shown it is not representative of the tritium in the sample [4]. The remaining $30 \mathrm{~mL}$ was then subsampled, in duplicate, for analysis using the same 3:22 sample to cocktail ratio as used on the unprocessed samples. These processed samples were then counted using the same 3-cycle, 10-minute protocol on the Packard Tri-Carb. The results of the analyses of the processed and unprocessed samples are shown in Figure 3. The errors reported for each data point are 1- $\sigma$ based on counting statistics for a single 30-minute count. Data points without error bars are minimum detectable activities (MDA) based on $2-\sigma$ counting statistics. Errors in the background and standard count rates were included in the error and MDA calculations. The qualitative conclusion from the data shown in this scatter plot suggests the processed samples yield a higher tritium concentration than the unprocessed samples, probably due to less quenching. To test the hypothesis, a linear regression analysis was performed on the data with results shown in Figure 4. The results indicate that the tritium concentrations in the processed samples are about $30 \%$ higher than the concentrations in the unprocessed samples on the average. The general conclusion from these experiments suggests that more accurate tritium concentrations are obtained on samples that have been purified from environmental contaminants at levels well below the $20 \mathrm{pCi} / \mathrm{mL}$ EPA Drinking Water Standard [6]. Samples $(50 \mathrm{~mL})$ that are routinely analyzed by the FDTAS are purified using the same EiChroM tritium columns after discarding the first $20 \mathrm{~mL}$ of eluant, but under higher flow rates $(5 \mathrm{~mL} /$ minute $)$.

\section{FDTAS Analyses}

The analyses of the river water composite samples were performed with the FDTAS while it was setup in a laboratory in the Savannah River Technology Center. The remote and process control computers for the FDTAS were located in the same laboratory. Sample processing is performed in the autosampler and mixing of the sample with liquid scintillation cocktail is performed external to the modified tritium analyzer. Two precision flow pumps deliver the sample and cocktail to a vortex mixer that overfills the analysis cell. Pulse height spectra are output from the tritium analyzer to the control computer for real-time data display and analysis. The sample handling protocol for FDTAS analysis of the river water samples was the following:

- Fill the sample cell with a 50:50 mixture of sample and Ultima-Gold LLT cocktail,

- drain the cell,

- refill the sample cell with the 50:50 sample/cocktail mixture,

- position the ${ }^{241}$ Am external standard source near the cell,

- count the sample/cocktail mixture during exposure to the ${ }^{241} \mathrm{Am}$ source for 5 minutes,

- lower the external standard into its internal shield,

- record the sample spectrum for 30 minutes,

- drain the cell, and 
- clean the cell.

To minimize sample cross contamination, the sample cell cleaning procedure was determined by careful visual examination of the cell and experiments alternating tritium standard solutions with background samples. The optimum cleaning protocol for this application was determined to be:

- Drain the cell and clear the lines with air.

- Fill the cell with methanol, allow to soak, scrub with an upward air flow, and drain.

- Repeat the above methanol cleaning steps.

- Fill the cell with deionized water, soak, air scrub, and drain.

- Repeat the above water cleaning steps two more times.

- Clear the lines with air.

The entire cleaning cycle took about 17 minutes and did not interfere with the routine sample analysis protocol. A low background water sample $(<0.005 \mathrm{pCi} / \mathrm{gm})$ obtained from a deep well aquifer (well P4) was run daily through the system as well as a NIST traceable tritium standard $(\sim 68 \mathrm{pCi} / \mathrm{mL})$ to verify the counting efficiency.

The analysis of the spectral data was performed using preset counting windows or regions of interest (RIO). Setting the ROIs was based on careful analyses of the spectra from tritium standard solutions and spectra taken with the external standard in position. The tritium analyzer is a modified Radiomatic 500TR Flow Scintillation Analyzer. The manufacturer's software was used to generate and interpret the spectral data in the remote computer. Four ROIs are possible with the standard software package. The ROIs for these experiments were set to optimize the counting window for the tritium beta, to assess the extent of cell filling, and to evaluate the extent of sample quenching.

To determine the best ROI settings to accomplish the above objectives, external standard source and tritium beta spectra were recorded. Figure 5 displays a typical spectrum of a $50 \%$ water loaded tritium standard in Ultima-Gold LLT cocktail and a typical background spectrum while exposed to the ${ }^{241} \mathrm{Am}$ external standard source. As the limit of detection of a measurement is determined by the signal-to-noise background ratio, the first two ROIs (Region 1 and Region 2) for tritium measurements were set from 0.5 to $6.25 \mathrm{keV}$ and 0.5 to $12 \mathrm{keV}$ respectively. This pair of ROIs also tests for quenching in the spectrum as it is shifted to lower energies. The two main features in the external standard spectrum are the low energy peak which simulates an unquenched tritium spectrum and the broad higher energy peak at $\sim 15 \mathrm{keV}$. Because of the efficient removal of all interfering radionuclides by the EiChroM resin, there is no beta interference in the high-energy region of the spectrum. The last two ROIs are set at 7-30 $\mathrm{keV}$ and $12-30 \mathrm{keV}$ respectively (Region 3 and Region 4) to confirm the extent of cell filling.

\section{FDTAS Analysis Results}


Both processed and unprocessed river water composite samples were analyzed using the FDTAS tritium analyzer as well as background samples from the P4 well and tritium standards. One sample was analyzed in replicate for precision measurements. The count rates in Region 3 (7-30 keV) for all samples when exposed to the ${ }^{241} \mathrm{Am}$ external standard are shown in Figure 6 . The term File Number on the abscissa has no quantitative meaning but is merely added to identify the observation. The highest count rate observed in the measurements is $\sim 280 \mathrm{cpm}$. Presumably, this corresponds to a completely filled cell with a $50 \%$ water loaded sample. The count rates are shown with a $1-\sigma$ error bar based on counting statistics for the 5-minute count. From these data, the sample volume $\left(V_{s}\right)$ of each sample was adjusted by:

$$
\mathrm{V}_{\mathrm{s}}=5.5 \mathrm{~mL} *[\mathrm{cpm}]_{\mathrm{Reg} 3} / 280 \mathrm{cpm}
$$

It can be seen from these data, the range of count rates observed during the external standard measurements was $180-280 \mathrm{cpm}$ which correspond to a range of sample volumes from 3.5 to $5.5 \mathrm{~mL}$ for a homogeneous, $50 \%$ water loaded sample. Factors which might affect this simple linear model include incomplete mixing, inadequate acclimation time to overcome flow fluorescence, temperature affects on flow rates caused by changes in scintillation fluid viscosity, and imprecise external standard positioning. For the purpose of this study, however, the volumes of sample, standard, and background were adjusted by this simple proportionality.

The ratio of count rates in the first two ROIs for all the samples analyzed by the FDTAS during this study is shown in Figure 7. The data are shown with $1-\sigma$ error bars. This ratio should reflect the extent of quenching in the samples. The conclusion from this plot is that the ratio of count rates is independent of sample type for the FDTAS. This is probably due to the purification of the samples through the EiChroM columns and the high water loading of the counting fluid mixture. The last few observations reflect some instrument calibration errors caused by an improper mixture of sample and cocktail.

One sample was analyzed nine times to determine the reproducibility of the FDTAS. The result of these replicate analyses is given in Figure 8. The error bars for the data shown in the figure are $2 \sigma$ based on counting statistics for all related parameters (sample, background, and standard count rates). The mean concentration for these nine measurements was $1.46 \mathrm{dpm} / \mathrm{mL}$ with a $0.47 \mathrm{dpm} / \mathrm{mL}$ error at the $95 \%$ confidence level or $660+/-220 \mathrm{pCi} / \mathrm{mL}$. The $1 \sigma$ error for a single determination would be $-230 \mathrm{pCi} / \mathrm{mL}$. Independent laboratory analyses of this sample using a distillation purification procedure [7] gave a tritium concentration of $1060+/-240 \mathrm{pCi} / \mathrm{mL}$. SRTC laboratory analysis of the same sample after purification through a single-use EiChroM column was $1390 \mathrm{H} /$ $540 \mathrm{pCi} / \mathrm{mL}$. Considering the low tritium concentrations in the sample and the uncertainty in the normal tritium backgrounds, these data appear to be consistent.

\section{Conclusions}

The prototype FDTAS has been shown to be a reliable instrument for measuring 
tritium at low concentrations in environmental samples. The advantages of remote operation and near real-time analysis results make it an instrument that can monitor critical locations for planned or unplanned releases and follow environmental surface water transport. A single point monitor would be significantly simpler in design with a purification system similar to the tritium effluent water monitor [8] presently in use at SRS. The multi-port capability of the prototype FDTAS makes it useful in monitoring ground water migration plumes. The operation and performance of the system has been confirmed by independent laboratory analyses of split samples. Detailed design of a second generation, field hardened multi-port FDTAS is required to produce a rugged, reliable system for repeated field deployments.

\section{Acknowledgments}

The authors would like to thank Wanda Matthews and Ron Johnson of the Radiometrics Group of SRTC for the countless hours of work done in preparation for this field demonstration and the extensive laboratory analyses. The continued support of this project by the researchers at the University of Georgia and the engineers at Sampling Systems, Inc. is also much appreciated. The work described herein was performed under Contract No. DE-AC09-89SR 18035 with the U. S. Department of Energy.

\section{References}

[1] J. Noakes, J. Spaulding, M. Neary, P. Cable, K. Hofstetter, Proceedings of the 5th Annual Conference on Low Level Liquid Scintillation Counting, Yokohama, Japan, June, 1996.

[2] P. Cable, K. Hofstetter, D. Beals, J. Jones, S. Collins, J. Noakes, J. Spaulding, M. Neary, R. Peterson, Proceedings of the 5th International Symposium on Field Analytical Methods for Hazardous Wastes and Toxic Materials, Las Vegas, January, 1997.

[3] K. Hofstetter, P. Cable, D. Beals, J. Noakes, J. Spaulding, M. Neary, and R. Peterson, "Field Deployable Tritium Analysis System for Ground and Surface Water Measurements", presented at MARC IV in Kona, HI, April 1997 and to be published in J. Radioanalytical and Nuclear Chemistry, (1998).

[4] D. Beals, P. Cable, K. Hofstetter, EiChroM Industries, Inc. 1996 Atlanta User's Seminar, May 1996, Atlanta, Ga.

[5] J. Noakes, R. Valenta, Proceedings of the International Conference on Advances in Liquid Scintillation Spectrometry, Glasgow, Scotland, August 8-12, 1994, Radiocarbon, University of Arizona, Tucson, 1996.

[6] Code of Federal Regulations, "National Primary Drinking Water Regulations"; 40CFR, Part 141, Washington DC, pp. 526-575 (1987).

[7] South Carolina Department of Health and Environmental Control, private 
communication, (February 1998).

[8] K. J. Hofstetter, "Continuous Aqueous Tritium Monitoring", Fusion Technology, Vol. $28,1527,(1995)$.

\section{List of Figures}

Figure 1. Schematic of the Field Deployable Tritium Analysis System

Figure 2. Analysis results for Savannah River composite samples taken Nov-Dec, 1997.

Figure 3. Tritium concentrations as determined by laboratory analyses of processed and unprocessed samples (see text).

Figure 4. Simple linear regression comparing tritium results of processed and unprocessed samples.

Figure 5a. Beta spectrum of tritium standard showing analysis regions of interest. Figure $5 \mathrm{~b}$. Spectrum of radiations produced in a background sample using the ${ }^{241} \mathrm{Am}$ external standard and the selected regions of interest to confirm cell filling.

Figure 6. Count rates in Region 3 for all samples during exposure to the ${ }^{241} \mathrm{Am}$ external standard.

Figure 7. Ratio of count rates in Region 2 to Region 3 for all samples analyzed in this study.

Figure 8. Concentrations of tritium measured in a Savannah River sample. 


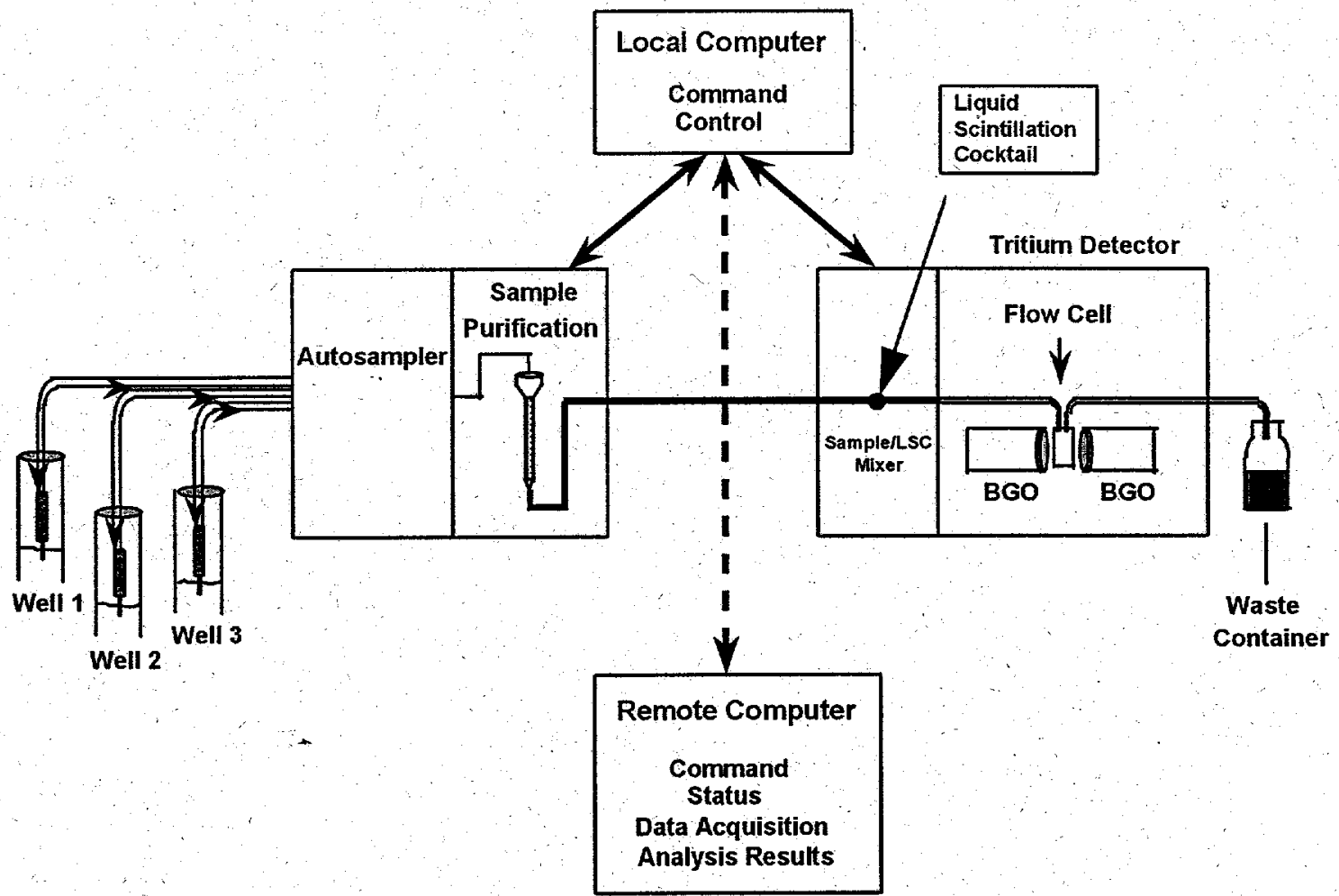




\section{Savannah River Tritium Concentration 12-hour Composites}

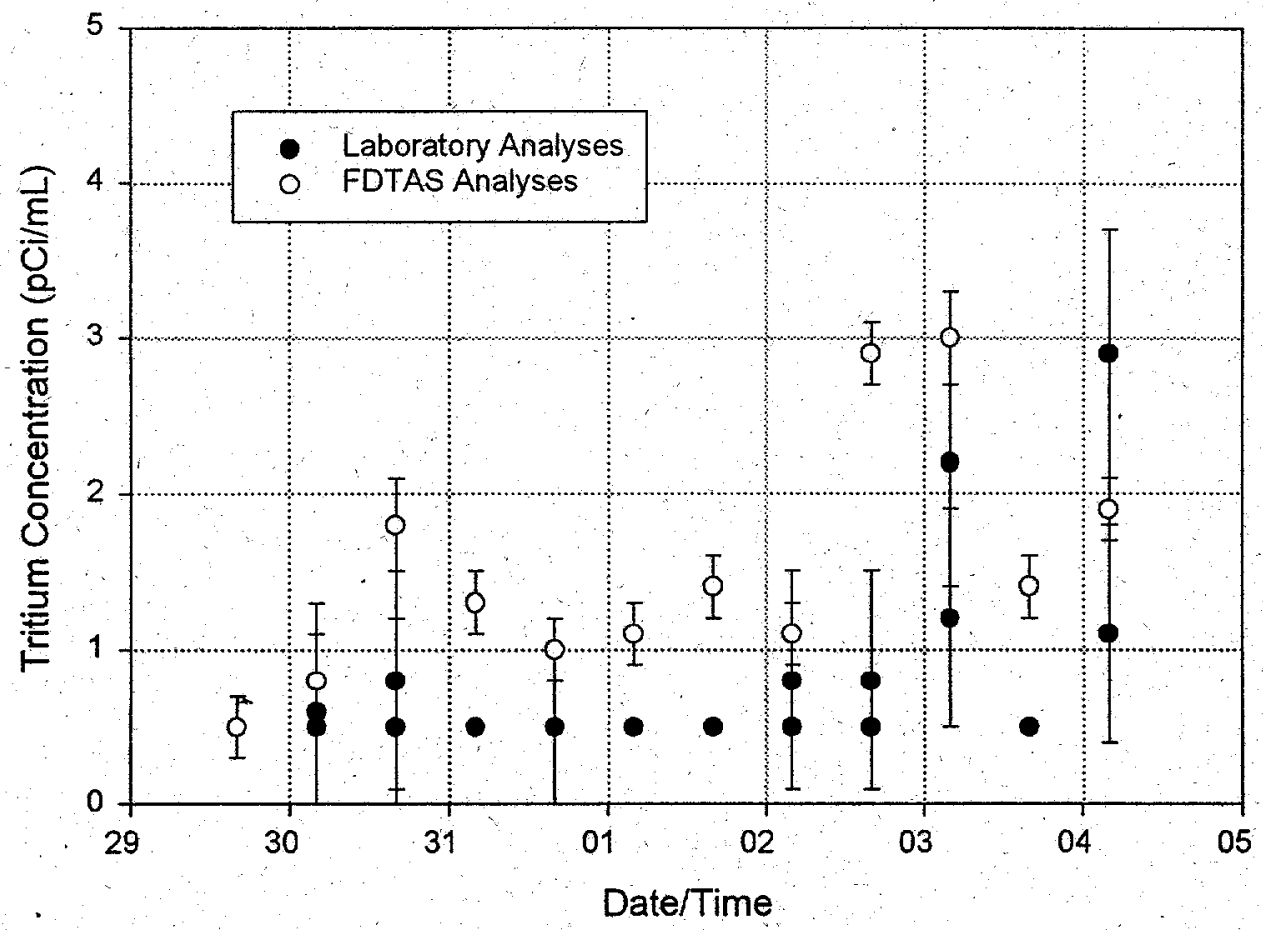


Savannah River Tritium from Composite Lab Analyses

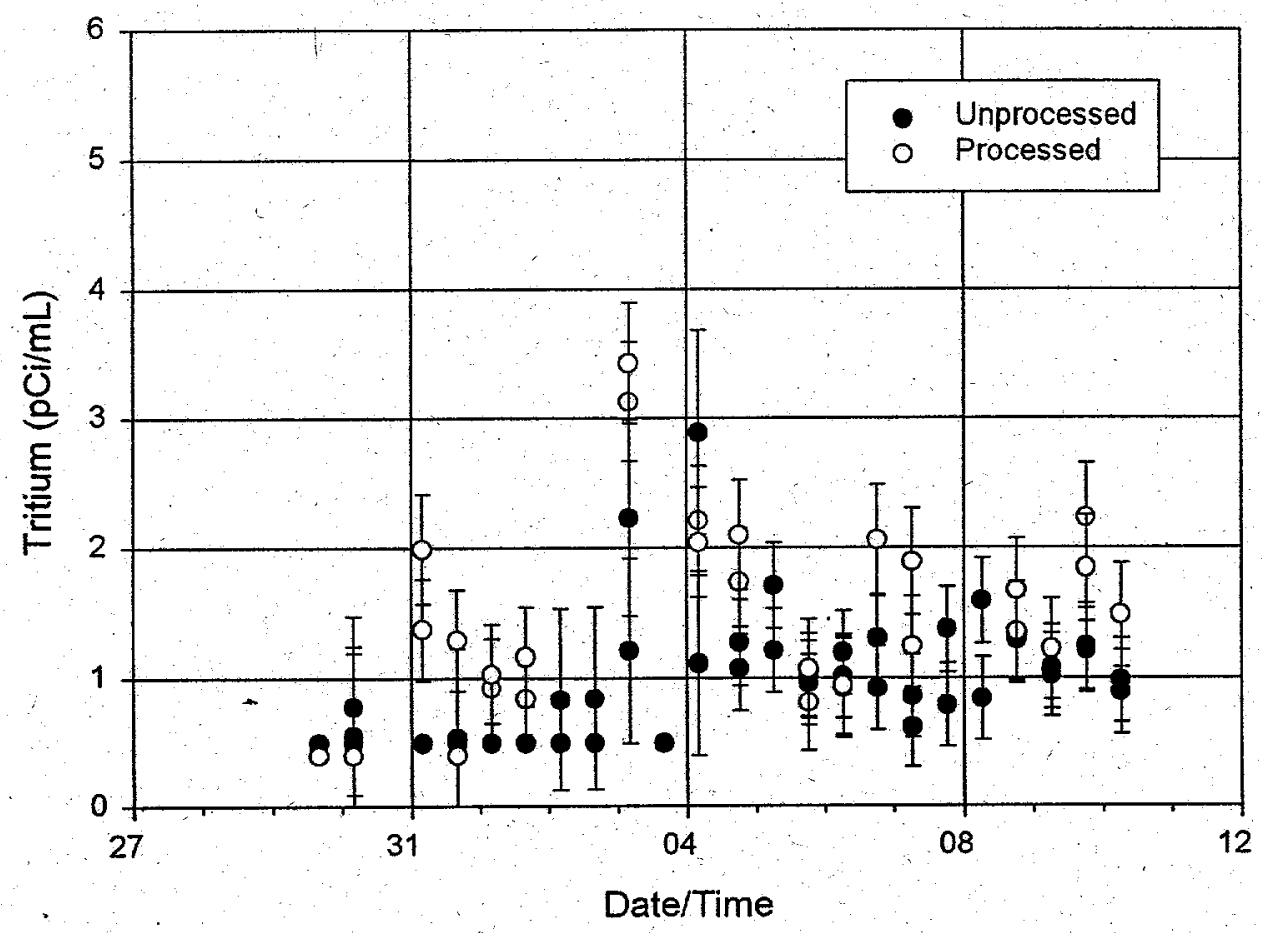




\section{Savannah River Composites \\ Lab Analyses \\ Tritium Concentration $(\mathrm{pCi} / \mathrm{mL})$}

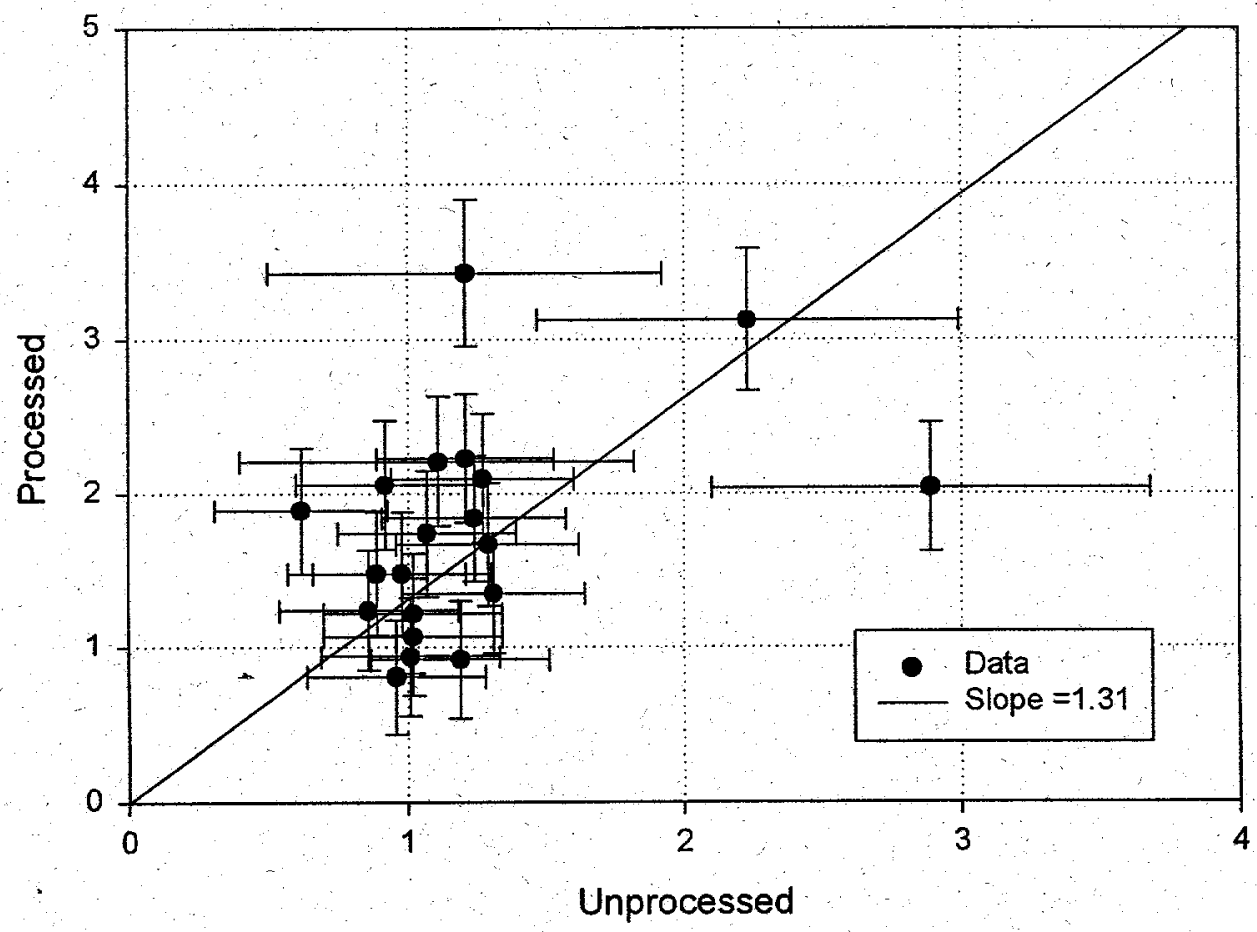




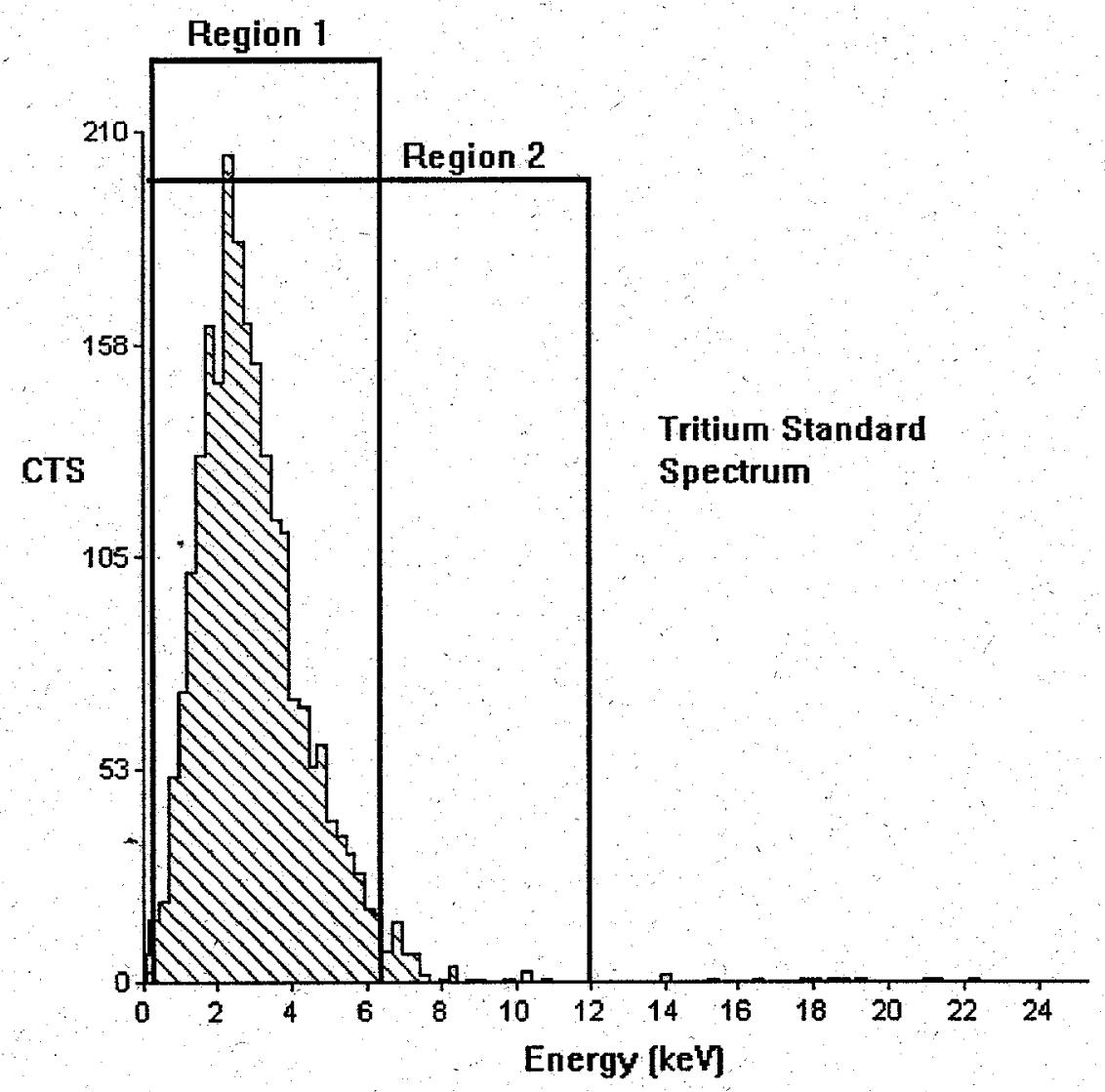




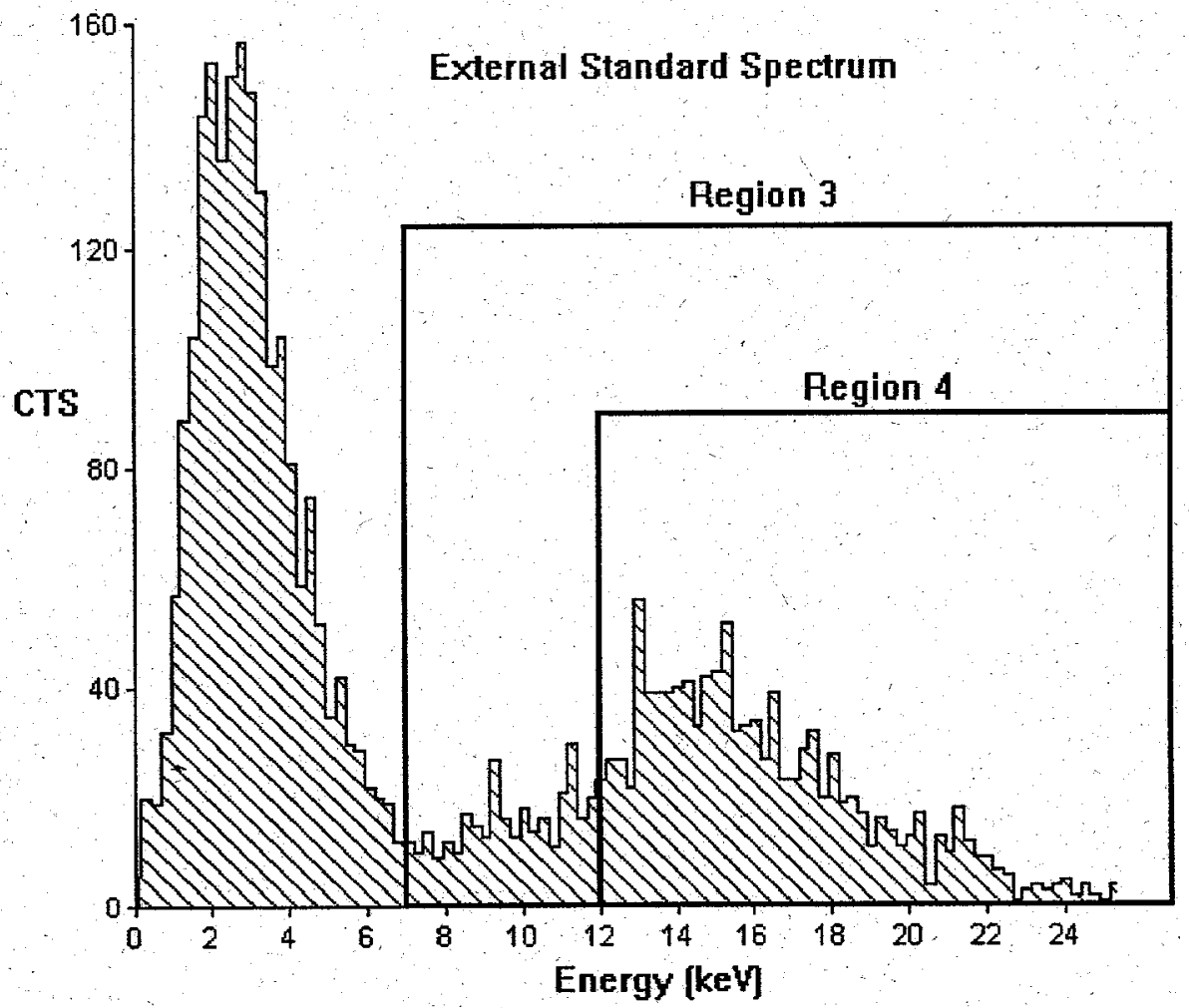


All Data

Region 3

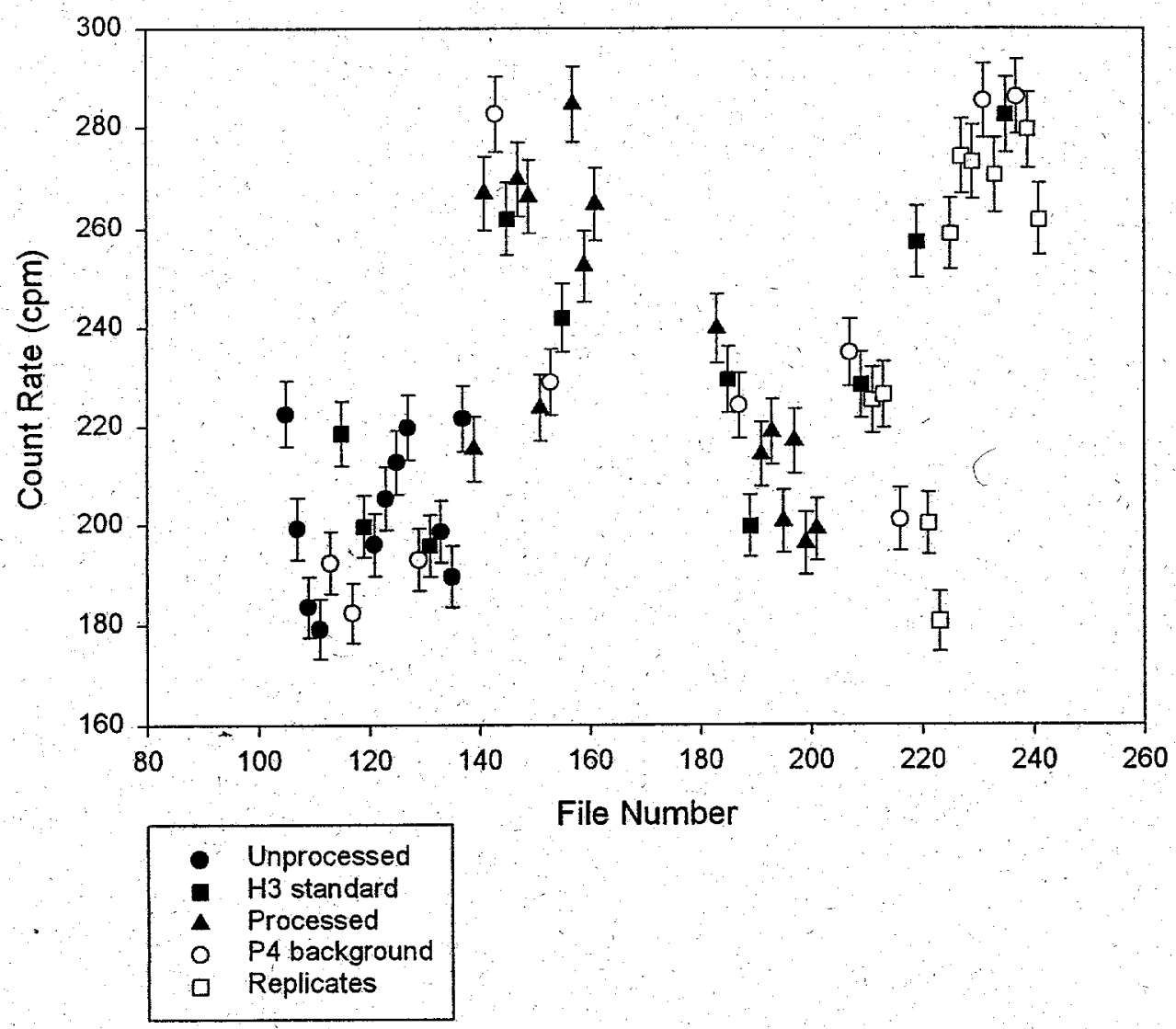


All Data

Region $2 /$ Region 1

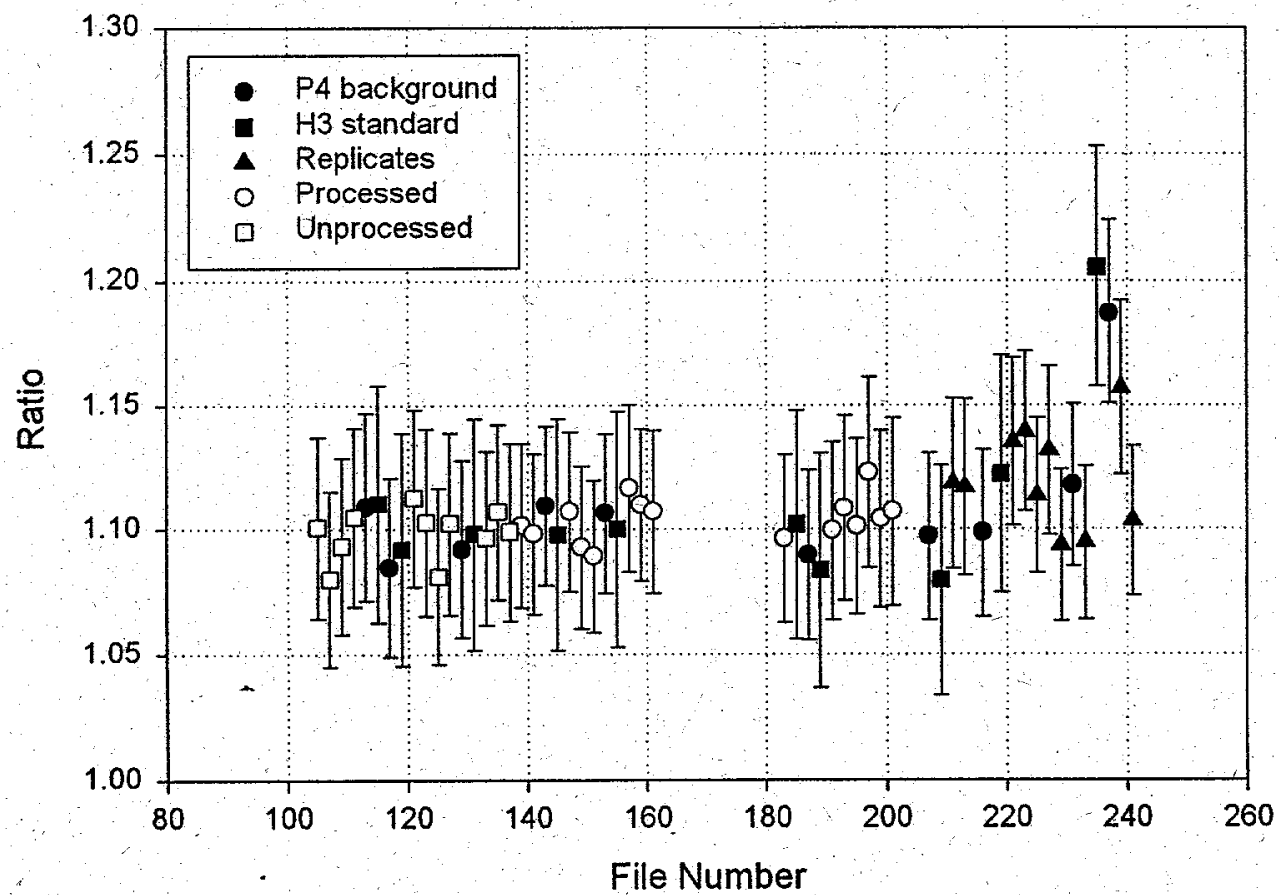


Replicate Data

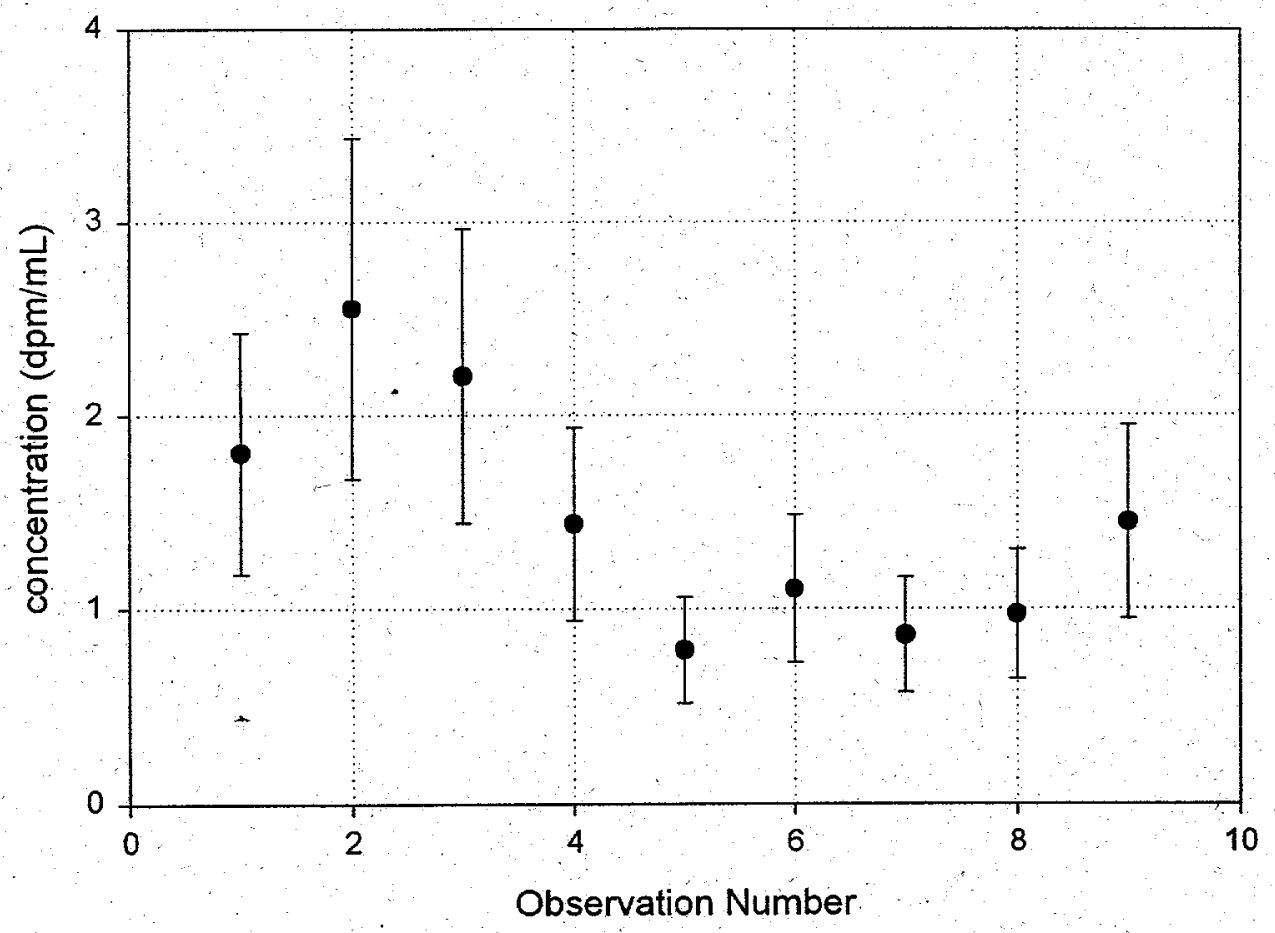

